\title{
PENGARUH CITRA MEREK DAN KEPUASAN KONSUMEN TERHADAP LOYALITAS KONSUMEN SIM CARD TELKOMSEL (Studi Pada Pengguna Sim Card Telkomsel di Ampana Kota)
}

\author{
ABD AZIS \\ (Dosen Fakultas Ekonomi Universitas Alkhairaat) \\ Alan Moharrang \\ (Mahasiswa Program Studi Manajemen Fakultas Ekonomi Universitas Alkhairaat)
}

\begin{abstract}
ABSTRAK
Tujuan penelitian ini adalah untuk mengetahui dan menganalisis pengaruh citra merek dan kepuasan konsumen terhadap loyalitas konsumen Sim Card Telkomsel. Populasi dalam penelitian ini adalah seluruh pengguna Sim Card Telkomsel di wilayah Ampana Kota Kabupaten Tojo Unauna Provinsi Sulawesi Tengah. Untuk mencapai tujuan tersebut ditarik sampel sebanyak 40 orang responden dengan metode Accidental Sampling, dan alat analisis yang digunakan adalah regresi linear berganda. Hasil penelitian ini menyimpulkan bahwa kedua variabel bebas yakni citra merek dan kepuasan konsumen baik secara serempak maupun parsial berpengaruh positif dan signifikan terhadap loyalitas konsumen Sim Card Telkomsel di Ampana Kota.
\end{abstract}

\section{Kata Kunci: Citra Merek, Kepuasan Konsumen, Loyalitas Konsumen}

\section{LATAR BELAKANG}

Era yang modern menuntut segala hal menjadi modern, hal ini menjadikan peluang sekaligus tantangan bagi pelaku bisnis. Seiring dengan kemajuan zaman, manusia sekarang sudah tidak ingin dengan suatu hal yang merepotkan, semua ingin sesuatu yang mudah dan instan. Kesibukan aktivitas sehari-hari membuat manusia sangat membutuhkan teknologi yang canggih dan mudah untuk mencari informasi dan hal-hal lainnya untuk meningkatkan pengetahuan dirinya.

International network atau yang biasa disebut internet dewasa ini menjadi sesuatu yang sangat berharga dan familiar di dunia ini. Dengan internet seseorang dapat dengan mudah mencari informasi, berkomunikasi jarak jauh dengan orang lain melalui situs jejaring sosial, berbisnis, bermain game, dan melakuan banyak hal-hal lainnya. Kehadiran perangkat mobile murah pintar semakin menjamur di pasaran. Harga perangkat gadget yang murah tersebut membuat penyebarannya menjadi lebih luas dan lebih cepat. Akibatnya, kebutuhan akan layanan data di Indonesia semakin meningkat seiring berjalannya waktu. Di wilayah perkotaan maupun pedesaan, layanan internet sudah menjadi sebuah kebutuhan yang kian membesar. Sayangnya, peningkatan kebutuhan itu tak diimbangi penyediaan fasilitas komunikasi yang ada di tengah masyarakat.

Pembangunan telekomunikasi di Indonesia bertujuan memberikan pelayanan yang memadai kepada masyarakat dan pemakai jasa telekomunikasi. Persaingan dunia industri yang semakin ketat secara langsung maupun tidak langsung mendorong setiap perusahaan industri, tidak terkecuali industri informasi dan telekomunikasi khususnya PT. Telekomunikasi Indonesia Tbk. Perkembangan teknologi komunikasi yang sangat pesat memberikan pengaruh yang sangat besar bagi perusahaan jasa telekomunikasi di Indonesia. Awal kelahiran Industri seluler di Indonesia didominasi oleh dua operator selular besar yang berbasis GSM (Global System for Mobile Communication), yaitu PT. Telkomsel (Telekomunikasi Seluler Indonesia) dan PT. Satelindo (http://www.telkomsel.co.id/).

PT. Telekomunikasi Seluler Indonesia (Telkomsel) merupakan salah satu perusahaan operator telekomunikasi seluler di Indonesia. Telkomsel adalah operator telekomunikasi seluler GSM pertama di Indonesia dengan layanan pascabayar kartu halo yang diluncurkan pada tanggal 26 Mei 1995. Sebelumnya, saham Telkomsel dimiliki oleh Telkom Indonesia sebesar 
$65 \%$ dan sisanya oleh Indosat (http://www.telkomsel.co.id/).

Berjalan dengan perkembangan zaman dan tekhnologi yang semakin meningkat bermunculanlah pesaing-pesaing dalam perusahaan komunikasi, yang ingin meraih keuntungan dan kesempatan dalam dunia komunikasi. Kemampuan perusahaan untuk mempertahankan bisnisnya di tengah persaingan yang semakin tajam dapat dikatakan sebagai suatu prestasi yang luar biasa. Di Indonesia sendiri terdapat beberapa perusahaan telekomunikasi yang memiliki kemampuan untuk mempertahankan bahkan mengembangkan kelangsungan bisnisnya di tengah persaingan yang tajam diantaranya PT. Telekomunikasi Selular Tbk (Telkomsel), PT. Indonesian Satellite Corporation Tbk (Indosat), dan PT. Excelcomindo Pratama Tbk (PT. XL Axiata Tbk). Persaingan yang semakin ketat membuat timbulnya suatu peningkatan kualitas dari suatu perusahaan. Peningkatan kualitas dilakukan dengan adanya perang tarif, penayangan iklan yang menarik, penambahan layanan. Hal ini membuat konsumen semakin banyak melakukan pemilihan produk terbaik dalam memenuhi kebutuhan dalam berkomunikasi.

Persaingan yang ketat mengharuskan perusahaan untuk memiliki strategi yang jitu untuk menciptakan sikap loyal pada konsumennya. Konsumen yang loyal merupakan suatu aset yang sangat berharga bagi perusahaan karena memiliki nilai strategis. Dimana dengan kesetiaan yang tinggi dari konsumen serta diikuti dengan minat beli pada produk pada akhirnya juga akan berdampak pada peningkatan penjualan perusahaan. Karena itu perusahaan senantiasa berusaha untuk memperoleh dan menciptakan kelompok pembeli yang tetap loyal pada produk atau jasanya atau berusaha menciptakan pasar yang stabil.

Usaha menciptakan dan mempertahankan konsumen hendaknya menjadi prioritas yang lebih besar bagi perusahaan. Strategi yang tepat dapat menarik konsumen hendaknya disusun secara cermat, agar konsumen mau membeli produk atau jasa yang dihasilkan perusahaan. Lebih dari itu, dengan segala kiatnya perusahaan hendaknya juga terus berupaya agar konsumen dapat menjadi konsumen yang setia.

Telkomsel merupakan perusahaan telekomunikasi yang mampu bersaing saat ini dan menjadi pemimpin pasar dan menjadi top brand di
Indonesia. Berdasarkan data menunjukan bahwa Telkomsel (Simpati) merupakan sim card dengan top brand tertinggi dari tahun 2015 sampai 2017. Hal ini membuktikan bahwa Telkomsel merupakan merek sim card yang paling mendominasi dibandingkan sim card lainnya. Berdasarkan hal tersebut, maka terlihat bahwa semakin baiknya merek maka semakin baik pula tingkat loyalitas yang dimiliki produk (http://www.telkomsel.co.id/).

Loyalitas konsumen tidak terjadi tanpa sebab, banyak sebab yang membuat konsumen menjadi loyal seperti kepuasan konsumen. Kepuasan konsumen merupakan reaksi jangka pendek konsumen terhadap kinerja jasa tertentu. Konsumen menilai tingkat kepuasan dan ketidakpuasan mereka setelah menggunakan jasa dan menggunakan informasi untuk memperbaharui persepsi mereka tentang kualitas, tetapi sikap terhadap kualitas tidak bergantung pada pengalaman. Konsumen tidak hanya menilai kepuasan berdasarkan informasi dari mulut ke mulut atau iklan perusahaan. Namun, konsumen harus benar-benar menggunakan suatu jasa untuk mengetahui puas atau tidaknya dengan hasilnya.

Menciptakan hubungan yang kuat dan erat dengan konsumen adalah mimpi semua pemasar dan hal ini sering menjadi kunci keberhasilan pemasaran jangka panjang perusahaan yang ingin membentuk ikatan konsumen yang kuat harus memperhatikan sejumlah pertimbangan yang beragam (Kotler dan Keller, 2009; 153).

Kepuasan dapat memberikan beberapa manfaat diantaranya hubungan antara perusahaan dan konsumen menjadi harmonis, menjadi dasar bagi pembelian ulang dan menciptakan loyalitas konsumen serta rekomendasi dari mulut ke mulut yang menguntungkan perusahaan (Tjiptono, 2011; 473). Jika konsumen puas dengan produk yang dibelinya maka akan timbul suatu loyalitas konsumen. Loyalitas didefinisikan sebagai suatu sikap yang ditunjukan kepada konsumen terhadap penyediaan produk atau jasa. Seorang konsumen akan menunjukkan sikap loyalnya jika suatu perusahaan mampu memberikan kepuasan terhadap konsumennya. Konsumen yang loyal adalah seorang konsumen yang selalu membeli kembali dari provider atau penyedia jasa yang sama dan memelihara suatu sikap positif terhadap penyedia jasa itu dimasa yang akan datang.

Disamping kepuasan konsumen, citra merek yang baik juga akan menciptakan suatu 
loyalitas konsumen, citra yang baik akan membuat konsumen tersebut percaya untuk mengkonsumsi produk atau jasa. Seiring waktu, merek berubah menjadi suatu simbol bagi konsumen dimana merek tertentu dianggap sebagai status, identifikasi diri, dan life style yang mewakili konsumen atau yang ingin dicapai oleh konsumen. Citra merek yang berbeda dan unik merupakan hal yang paling penting, karena produk semakin kompleks dan pasar semakin penuh, sehingga konsumen akan semakin bergantung pada citra merek daripada atribut merek yang sebenarnya untuk mengambil keputusan pembelian.

Berdasarkan uraian diatas, peneliti ingin mengkaji lebih jauh fenomena sebagaimana uraian diatas dalam sebuah penelitian yang berjudul "Pengaruh Citra Merek dan Kepuasan Konsumen Terhadap Loyalitas Konsumen Sim Card Telkomsel (Studi Pada Pengguna Sim Card Telkomsel di Ampana Kota)". Adapun permasalahan dalam penelitian ini adalah sebagai berikut:

1. Apakah citra merek dan kepuasan konsumen secara serempak berpengaruh terhadap loyalitas konsumen Sim Card Telkomsel?

2. Apakah citra merek berpengaruh terhadap loyalitas konsumen Sim Card Telkomsel?

3. Apakah kepuasan konsumen berpengaruh terhadap loyalitas konsumen Sim Card Telkomsel?

\section{KAJIAN PUSTAKA \\ Loyalitas Konsumen}

Dalam dekade 2000-an, orientasi perusahaan kelas dunia mengalami pergeseran dari pendekatan konvensional ke arah pendekatan kontemporer. Pendekatan konvensional menekankan kepuasan pelanggan, reduksi biaya, pangsa pasar dan riset pasar. Sedangkan pendekatan kontemporer berfokus pada loyalitas pelanggan, retensi pelanggan, zero defections, dan lifelong customers (Tjiptono, 2006; 385).

Menurut Griffin (2009; 31), loyalitas konsumen didefinisikan sebagai suatu sikap yang ditunjukan kepada konsumen terhadap penyediaan produk atau jasa. Seorang konsumen akan menunjukkan sikap loyalnya jika suatu perusahaan mampu memberikan kepuasan terhadap konsumennya. Konsumen yang loyal adalah seorang konsumen yang selalu membeli kembali dari provider atau penyedia jasa yang sama dan memelihara suatu sikap positif terhadap penyedia jasa itu dimasa yang akan datang.
Menurut Lovelock (2007; 338), loyalitas konsumen yaitu kesediaan konsumen untuk terus berlangganan pada sebuah perusahaan dalam jangka panjang, dengan membeli dan menggunakan barang dan jasanya secara berulang-ulang dan lebih baik lagi secara eksklusif, dan dengan sukarela merekomendasikannya kepada pihak lain. Kesetiaan konsumen tidak terbentuk dalam waktu singkat tetapi melalui proses belajar dan berdasarkan hasil pengalaman dari konsumen itu sendiri dari pembelian konsisten sepanjang waktu. Bila yang didapat sudah sesuai dengan harapan, maka proses pembelian ini terus berulang. Hal ini dapat dikatakan bahwa telah timbul kesetiaan konsumen. Bila dari pengalamannya, konsumen tidak mendapatkan merek yang memuaskan maka ia tidak akan berhenti untuk mencoba merekmerek lain sampai ia mendapatkan produk atau jasa yang memenuhi kriteria yang mereka tetapkan.

Menurut Griffin (2009; 34) konsumen yang loyal adalah konsumen yang memiliki karakteristik sebagai berikut:

1) Melakukan pembelian ulang secara teratur (makes reguler repeat purchase).

Loyalitas lebih mengacu pada wujud perilaku dari unit-unit pengambilan keputusan untuk melakukan pembelian secara terus menerus terhadap barang/jasa suatu perusahaan yang dipilih. Tingkat kepuasan terhadap toko akan mempengaruhi mereka untuk membeli kembali.

2) Membeli di luar lini produk/jasa (purchases across product and service lines).

Membeli di luar lini produk dan jasa artinya keinginan untuk membeli lebih dari produk dan jasa yang telah ditawarkan oleh perusahaan. Pelanggan yang sudah percaya pada perusahaan dalam suatu urusan maka akan percaya juga untuk urusan lain.

3) Mereferensi toko kepada orang lain (refers other).

Pelanggan yang loyal dengan sukarela merekomendasikan perusahaan kepada temanteman dan rekannya.

4) Menunjukkan kekebalan daya tarik dari pesaing (demonstrates an immunity to the full of the competition).

Tidak mudah terpengaruh oleh tarikan persaingan perusahaan sejenis lainnya. 


\section{Citra Merek}

Citra merek bagi konsumen merupakan suatu pegangan yang penting dalam sebuah keputusan. Citra merek dapat dianggap sebagai asosiasi yang muncul dalam benak konsumen ketika mengingat suatu merek tertentu. Dan asosiasi tersebut akan muncul dalam bentuk pemikiran citra yang dikaitkan dengan suatu merek. Citra merek pada dasarnya adalah hasil pandangan atau presepsi konsumen terhadap suatu merek tertentu yang didasarkan atas pertimbangan dan perbandingan dengan beberapa merek lain.

Menurut Kotler dan Keller (2009; 346), citra merek (brand image) adalah sekumpulan asosiasi merek yang terbentuk dan melekat di benak konsumen. Konsumen yang terbiasa menggunakan merek tertentu cenderung memiliki konsistensi terhadap brand image. Citra merek ialah persepsi dan keyakinan yang dilakukan oleh konsumen, seperti tercermin dalam asosiasi yang terjadi dalam memori konsumen.

Menurut Rangkuti $(2009 ; 24)$ citra merek (brand image) adalah sekumpulan asosiasi merek yang terbentuk dan melekat di benak konsumen. Konsumen yang terbiasa menggunakan merek tertentu cenderung memiliki konsistensi terhadap brand image.

Menurut Rangkuti (2009; 26) mengemukakan citra merek merupakan komponen utama dari pengetahuan merek yang meliputi pesan merek yang akan dibagi lagi menjadi empat bagian yaitu:

a. Kind association brand, yang memiliki tiga bagian penting yaitu atribut, keuntungan dan perilaku.

b. Favorability association brand, yaitu asosiasi merek yang baik diciptakan dengan meyakinkan konsumen bahwa merek memiliki kesesuaian atribut dan cukup bermanfaat bagi mereka yang butuh dan ingin.

c. Strength association brand, yaitu asosiasi produk yang menyiratkan kekuatan atau mutu produk.

d. Uniqueness of brand association, yaitu asosiasi produk yang menyiratkan keunggulan atas merek lain.

Sedangkan menurut Kotler dan Keller (2009; 348) bahwa pengukur citra merek dapat dilakukan berdasarkan pada aspek sebuah merek yaitu:

1) Kekuatan (Strengthness)

Dalam hal ini adalah keunggulan yang dimiliki oleh merek yang bersifat fisik dan tidak ditemukan pada merek lainya. Keunggulan merek ini mengacu pada atribut-atribut fisik atas merek tersebut sehingga bisa dianggap sebagai sebuah kelebihan dibanding dengan merek lainnya. Yang termasuk pada sekelompok kekuatan (Strength): penampilan fisik, keberfungsian semua fasilitas produk, harga produk, maupun fasilitas pendukung dari produk tersebut.

2) Keunikan (Uniqueness)

Adalah kemampuan untuk membedakan sebuah merek diantara merek lainnya. Kesan ini muncul dari atribut produk tersebut yang menjadi bahan pembeda atau difrensiasi dengan produk-produk lainnya. Yang termasuk dalam kelompok unik ini adalah variasi layanan, variasi harga, maupun penampilan atau nama dari sebuah merek dan fisik produk itu sendiri.

3) Bersifat baik (Favorable)

Yang termasuk dalam kelompok favorable ini antara lain kemudahan merek produk diucapkan serta kemampuan merek untuk tetap di ingat oleh pelanggan maupun kesesuaian antara kesan merek di benak pelanggan dengan citra yang diinginkan perusahaan atas merek yang bersangkutan.

\section{Kepuasan Konsumen}

Kepuasan konsumen menjadi salah satu hasil penting dari semua aktivitas pemasaran, sebab puas tidaknya konsumen akan berdampak pada keberhasilan perusahaan. Oleh karena itu perusahaan selalu berusaha untuk dapat memuaskan pelanggannya atas barang/jasa yang telah diproduksinya. Swan dalam Tjiptono (2006; 169), mendefinisikan kepuasan pelanggan atau kepuasan konsumen sebagai evaluasi secara sadar atau penilaian kognitif menyangkut apakah kinerja produk relatif bagus atau jelek atau apakah produk bersangkutan cocok atau tidak cocok dengan tujuan atau pemakaian.

Menurut Tse dan Wilton dalam Tjiptono (2006; 169), mengemukakan bahwa kepuasan konsumen adalah respon konsumen terhadap evaluasi persepsi atas perbedaan antara harapan awal sebelum pembelian (atau standar kinerja lainnya) dan kinerja aktual produk sebagaimana dipersepsikan setelah memakai atau mengkonsumsi produk bersangkutan. Sedangkan menurut Kotler $(2007$; 141) kepuasan konsumen adalah sejauh mana kinerja yang diberikan oleh sebuah produk sepadan dengan harapan pembeli. 
Jika kinerja produk kurang dari yang diharapkan itu, pembelinya tidak akan merasa puas. Pelanggan yang merasa puas akan kembali membeli, dan mereka akan memberitahukan kepada yang lain tentang pengalaman baik mereka dengan produk tersebut.

Tjiptono (2006; 173) menjelaskan bahwa adapun faktor-faktor yang mempengaruhi kepuasan konsumen sebagai berikut:

1) Nilai konsumen

Yaitu ikatan emosional yang terjalin antara konsumen dan produsen setelah konsumen menggunakan produk dan jasa dari perusahaan dan mendapati bahwa produk atau jasa tersebut memberi nilai tambah. Hal-hal yang berkaitang dengan nilai konsumen ini antara lain, yaitu: menerima atas keluhan konsumen, tanggap atas keluhan konsumen, memiliki banyak jenis pelayanan, dan memberikan informasi dengan baik terhadap sesuatu yang dibutuhkan konsumen

2) Respon konsumen

Tanggapan yang diberikan para konsumen setelah terpenuhinya kebutuhan mereka akan sebuah produk ataupun jasa, sehingga para konsumen memperoleh rasa nyaman dan senang karena harapannya telah terpenuhi. Respon konsumen ini antara lain yaitu: tetap setia lebih lama dengan produk yang digunakan, membeli lebih banyak ketika perusahaan memperkenalkan produk baru dan memperbaharui produk-produk yang ada, serta memberi perhatian yang lebih sedikit kepada merek-merek lainnya.

3) Persepsi konsumen

Persepsi konsumen adalah proses ketika seseorang memilih, mengorganisasi dan menginterpretasikan informasi yang datang menjadi suatu arti tersendiri untuk menciptakan gambaran secara keseluruhan atas produk yang digunakannya. Persepsi konsumen ini diantaranya yaitu: konsumen merasa puas dengan proses dan pelayanan yang diberikan, konsumen merasa aman dan nyaman selama berurusan dengan perusahaan tersebut, serta konsumen memberikan saran untuk keluhan konsumen baik melalui kotak saran atau $e$-mail.

\section{Hubungan Citra Merek Dengan Loyalitas Konsumen}

Citra yang dimiliki merek di dalam pikiran konsumen cenderung memberikan kontribusi yang lebih penting terhadap kesuksesan sebuah merek dibandingkan karakteristik aktual yang dimiliki merek, sehingga pemasar berusaha untuk menciptakan citra merek/produk yang konsisten dengan citra diri konsumen yang kirakira sesuai pada segmen pasar yang ditargetkan. Hasil dari kesuksesan strategi ini adalah dimana konsumen mengandalkan citra merek dalam pemilihan produk atau jasa (Kotler dan Keller, 2009; 289).

Citra merek yang berbeda dan unik merupakan hal yang paling penting, karena produk semakin kompleks dan pasar semakin penuh, sehingga konsumen akan semakin bergantung pada citra merek daripada atribut merek yang sebenarnya untuk mengambil keputusan pembelian (Schiffman dan Kanuk, 2008; 141). Konsumen cenderung memilih berdasarkan citra merek, terutama ketika konsumen itu tidak memiliki pengalaman dengan produk dalam kategori tertentu yang tidak pernah mereka beli, mereka akan cenderung untuk "percaya" pada produk dengan nama merek yang terkenal atau favorit. Konsumen sering berpikir bahwa merek yang terkenal merupakan produk yang lebih baik dan lebih bernilai untuk dibeli karena tersirat jaminan akan kualitas, dapat diandalkan dan pelayanan yang lebih baik. Usaha promosi sebuah merek mendukung pemahaman mengenai kualitas produk mereka dengan membangun dan mempertahankan citra merek yang positif dalam benak konsumen (Schiffman dan Kanuk, 2008; 143).

\section{Hubungan Kepuasan Konsumen Dengan Loyalitas Konsumen \\ Menurut Oliver dalam Tjiptono (2006;} 171), produk dan layanan yang berkualitas berperan penting dalam membentuk kepuasan konsumen, selain itu juga erat kaitannya dalam menciptakan keuntungan bagi perusahaan. Semakin berkualitas produk dan layanan yang diberikan oleh perusahaan maka kepuasan yang dirasakan oleh pelanggan akan semakin tinggi. Adanya kepuasan pelanggan akan dapat menjalin hubungan harmonis antara produsen dan konsumen. Menciptakan dasar yang baik bagi pembelian ulang serta terciptanya loyalitas pelanggan dan membentuk rekomendasi dari mulut ke mulut yang akan dapat menguntungkan sebuah perusahaan.

Menurut Kotler dan Armstrong (2008; 8), konsumen membentuk ekspetasi tentang nilai 
dan kepuasan yang akan diberikan berbagai penawaran pasar dan membeli berdasarkan ekspetasinya itu. Konsumen yang puas akan membeli lagi dan memberitahu orang lain tentang pengalaman baik mereka. Konsumen yang tidak puas sering berganti ke pesaing dan menjelekjelekan produk yang mereka beli kepada orang lain.

Pelanggan membentuk ekspektasi tentang nilai dan kepuasan yang akan diberikan berbagai penawaran pasar dan membeli berdasarkan ekspetasinya itu. Konsumen yang puas akan membeli lagi dan memberitahu orang lain tentang pengalaman baik mereka. Konsumen yang tidak puas sering berganti ke pesaing dan menjelek-jelekan produk yang mereka beli kepada orang lain. Dalam pengujian kepuasan konsumen dibutuhkan suatu manajemen hubungan konsumen (costumer relationship management-CRM), yang dimana dalam manajemen hubungan konsumen adalah keseluruhan proses membangun dan memelihara hubungan konsumen yang menguntungkan dengan menghantarkan nilai dan kepuasan yang unggul. Proses ini berhubungan dengan semua aspek untuk meraih, mempertahankan, dan menumbuhkan konsumen (Kotler, 2007; 153).

\section{METODE PENELITIAN \\ Populasi dan Sampel}

Populasi merujuk pada sekumpulan orang atau objek yang memiliki kesamaan dalam satu atau beberapa hal dan yang membentuk masalah pokok dalam suatu riset khusus (Sugiyono, 2007). Dalam hal ini populasinya adalah pengguna atau konsumen Sim Card Telkomsel di Kota Ampana.

Sampel merupakan bagian yang berguna bagi tujuan penelitian populasi dan aspekaspeknya. Sampel adalah bagian dari populasi yang diambil untuk diteliti. Metode pengambilan sampel dilakukan dengan cara Accidental Sampling yaitu bentuk pengambilan sampel berdasarkan kebetulan dimana, siapa saja yang kebetulan bertemu dengan peneliti dan dianggap cocok menjadi sumber data yang akan menjadi sampel penelitian ini (Sugiyono, 2007).

Pada penelitian ini, populasi yang diambil berukuran besar dan jumlahnya tidak diketahui. Penentuan jumlah sampel menurut Hair (1998) yang memegang peranan penting dalam estimasi dan interpretasi hasil maka ukuran sampel yang ideal dan respresentatif adalah tergantung pada jumlah variabel bebas (independent) dikalikan 15 sampai dengan 20. Dengan demikian sampel minimal untuk penelitian ini yang memiliki variabel bebas sebanyak 2 adalah 2 × $20=40$ orang. Dalam penelitian ini akan digunakan jumlah sampel sebagaimana formulasi yang dikemukakan dalam teori Hair. Untuk mendapatkan estimasi dan interpretasi yang baik dari penelitian ini maka sampel yang diteliti ditetapkan sebanyak 40 responden.

\section{Defenisi Operasional Variabel}

Untuk memperjelas variabel-variabel yang digunakan dalam penelitian ini, dikemukakan batasan-batasan definisi operasional yang akan digunakan sebagai bahan acuan dan dijabarkan dalam bentuk kuesioner. Variabel-variabel sebagai berikut:

1) Loyalitas Konsumen (Y)

Loyalitas konsumen yaitu kesediaan konsumen untuk terus berlangganan pada sebuah perusahaan dalam jangka panjang, dengan membeli dan menggunakan barang dan jasanya secara berulang-ulang dan lebih baik lagi secara eksklusif, dan dengan sukarela merekomendasikannya kepada pihak lain. Adapun indikator dari loyalitas konsumen menurut Griffin (2009; 34), yaitu: melakukan pembelian ulang secara teratur (makes reguler repeat purchase, membeli di luar lini produk/jasa (purchases a cross product and service lines), mereferensi toko kepada orang lain (refers other), dan menunjukkan kekebalan daya tarik dari pesaing (demonstrates an immunity to the full of the competition).

2) Citra Merek $\left(X_{1}\right)$

Citra merek adalah deskripsi tentang asosiasi dan keyakinan konsumen terhadap merek tertentu. Citra merek itu sendiri memiliki arti kepada suatu pencitraan sebuah produk dibenak konsumen secara massal. Citra konsumen yang positif terhadap suatu barang akan memberikan presepsi yang baik bagi merek tersebut. Menurut Kotler dan Keller (2009; 348) bahwa pengukur citra merek dapat dilakukan berdasarkan pada aspek sebuah merek yaitu: kekuatan (Strengthness), keunikan (Uniqueness), dan bersifat baik (Favorable). 
3) Kepuasan Konsumen $\left(\mathrm{X}_{2}\right)$

Kepuasan konsumen adalah perbandingan antara layanan atau hasil yang diterima konsumen dengan harapan konsumen, dimana layanan atau hasil yang diterima tersebut paling tidak sama dengan harapan konsumen atau bahkan bisa melebihinya. Tjiptono (2006; 173) menjelaskan bahwa adapun faktor-faktor yang mempengaruhi kepuasan konsumen yaitu: nilai konsumen, respon konsumen, dan persepsi konsumen.

\section{Uji Validitas}

Menurut Sugiyono (2011; 62) menjelaskan bahwa uji validitas dinyatakan valid berarti instrumen tersebut dapat digunakan untuk mengukur apa yang seharusnya diukur. Valid menunjukan derajat ketepatan antara data yang sesungguhnya terjadi pada objek dengan data yang dapat dikumpulkan oleh peneliti. Yang dimaksud dengan uji validitas adalah suatu data dapat dipercaya kebenarannya sesuai dengan kenyataan.

Valid tidaknya suatu alat ukur tergantung pada kemampuan atau tidak alat ukur tersebut mencapai tujuan pengukuran yang dikehendaki. Data dikatakan valid apabila nilai probabilitas atau dalam output SPSS disebut Sig.2 tailed lebih kecil dari 5\% (level of significance) atau 0,05 nilai alpha menunjukkan bahwa pernyataan-pernyataan tersebut sudah valid. Selanjutnya apabila nilai probabilitas (Sig.2 tailed) lebih besar dari nilai alpha $=0,05$ maka item pernyataan kuesioner tersebut berstatus tidak valid atau tidak tepat dalam menjelaskan variabelnya sehingga butir tersebut dinyatakan gugur sehingga tidak digunakan dalam penelitian selanjutnya.

Berdasarkan hasil analisis uji validitas dinyatakan bahwa semua instrumen layak diikutsertakan dalam penelitian ini, karena nilai probabilitas atau Sig. 2 tailed lebih kecil dari taraf signifikansi alpha $(\alpha)$ 0,05 dan semua item pernyataan kuesioner berstatus valid atau tepat dalam menjelaskan variabelnya.

\section{Uji Reliabilitas}

Selain valid sebuah instrumen juga harus reliabel (dapat dipercaya). Instrumen yang reliabel adalah instrumen yang bila digunakan beberapa kali untuk mengukur objek yang sama, akan menghasilkan data yang sama. Artinya, bahwa instrumen selain harus sesuai dengan kenyataan juga harus memiliki nilai ketepatan, dimana apabila instrumen ini diberikan pada kelompok yang sama dengan waktu yang berbeda akan sama hasilnya. Untuk mengukur reliabilitas yaitu melalui uji statistik cronbach alpha dan variabel dikatakan reliabel jika nilai cronbach alpha $>0.60$ (Sugiyono, 2011; 68). Hasil pengujian reliabilitas dilakukan terhadap setiap variabel penelitian ini terlihat dalam tabel berikut:

Tabel 1. Hasil Uji Reliabilitas

\begin{tabular}{|l|c|c|}
\hline \multicolumn{1}{|c|}{ Variabel Penelitian } & $\begin{array}{c}\text { Alpha } \\
\text { Cronbach }\end{array}$ & Keterangan \\
\hline Citra Merek & 0.632 & Reliabel \\
\hline Kepuasan Konsumen & 0.602 & Reliabel \\
\hline Loyalitas Konsumen & 0.715 & Reliabel \\
\hline
\end{tabular}

Hasil uji reliabilitas sebagaimana Tabel 1 menunjukkan bahwa sesungguhnya instrumen penelitian yang diajukan dalam bentuk kuesioner yang digunakan dalam penelitian ini reliabel atau andal. Hal ini disebabkan karena besarnya nilai Alpha Cronbach diatas 0.60 yang berarti memenuhi syarat minimal.

\section{Uji Asumsi Klasik}

Pengujian asumsi klasik atau di sebut asumsi regresi bertujuan mengetahui kelayakan model persamaan regresi yang dihasilkan. Jika model persamaan memenuhi asumsi tersebut maka persamaan regresi terbebas dari penyakit regresi. Beberapa asumsi klasik yaitu:

1) Uji Multikolinearitas

Multikolinearitas adalah keadaan dimana pada model regresi ditemukan adanya korelasi yang sempurna atau mendekati sempurna antar variabel independen (Priyatno, 2012; 151). Uji Multikolinearitas dapat dilakukan dengan melihat nilai Tolerance dan Variance Inflation Factor (VIF). Jika nilai tolerance lebih besar dari 0,1 atau nilai VIF lebih kecil dari 10 , maka model regresi dinyatakan tidak terdapat gejala multikolinearitas (Ghozali, 2005; 91). Berdasarkan output SPSS versi 20.0, dapat dilihat hasil uji multikolinearitas untuk masing-masing variabel independen pada tabel berikut: 
Tabel 2. Hasil Uji Multikolinearitas

\begin{tabular}{|l|l|l|}
\hline \multirow{2}{*}{\multicolumn{1}{|c|}{ Model }} & \multicolumn{2}{|c|}{ Collinearity Statistics } \\
\cline { 2 - 3 } & Tolerance & VIF \\
\hline (Constant) & & \\
Citra Merek & 0.281 & 3.553 \\
Kepuasan Konsumen & 0.281 & 3.553 \\
\hline
\end{tabular}

Dari nilai pada tabel 3.4 dapat dilihat nilai Tolerance seluruh variabel independen lebih besar dari 0,10, yang berarti tidak ada korelasi antar variabel independen. Hasil perhitungan nilai Variance Inflation Factor (VIF) juga menunjukan hal yang sama, seluruh variabel independen memiliki nilai VIF di bawah dari angka 10, maka dapat dikatakan bebas dari gejala multikolinearitas. Dengan demikian dapat disimpulkan bahwa tidak ada multikolinearitas antar variabel independen dalam model regresi.

\section{2) Uji Normalitas}

Uji normalitas bertujuan untuk menguji apakah dalam sebuah model regresi, variabel independen, variabel dependen atau keduanya mempunyai distribusi normal. Model regresi yang baik adalah distribusi data normal atau mendekati normal. Normalitas data dapat dilakukan dengan melihat probability plot (p-plot), dimana normalitas data dapat dideteksi dengan cara melihat peyebaran data (titik) pada sumbu diagonal dari grafik. Jika data menyebar di sekitar garis diagonal dan mengikuti arah garis diagonal, maka model regresi memenuhi asumsi normalitas dan sebaliknya (Ghozali, 2005; 93). Berikut hasil uji normalitas dengan melihat grafik p-plot.

\section{Gambar 3.1 \\ Grafik Normal Probability-Plot}

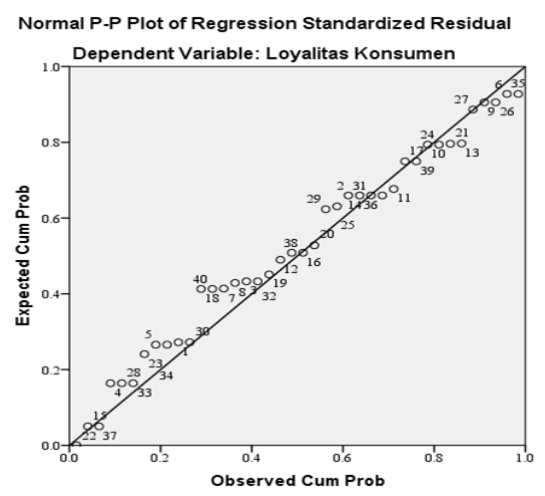

Dari grafik Normal P-Plot terlihat bahwa titik menyebar di sekitar garis diagonal, serta penyebarannya mengikuti garis diagonal maka dapat disimpulkan bahwa model regresi dalam penelitian ini memenuhi asumsi normalitas.

3) Uji Heterokedastisitas

Uji heteroskedastisitas dilakukan untuk menguji apakah dalam model regresi terjadi ketidaksamaan varians residual dari pengamatan ke pengamatan lain. Dalam sebuah model regresi terdapat kesamaan varians dari residu dari satu pengamatan ke pengamatan lain sama, maka disebut homoskedastisitas dan jika varians berbeda disebut heterokedastisitas. Dasar keputusan menyangkut asumsi heterokedastisitas didasarkan pada grafik Scatterplot dengan pedoman yaitu jika ada pola tertentu, seperti titik-titik (poin-poin) yang ada membentuk suatu pola tertentu yang teratur (bergelombang, melebar kemudian menyempit), maka telah terjadi heterokedastisitas. Namun jika tidak ada pola yang jelas, serta titik-titik menyebar di atas dan dibawah angka nol pada sumbu Y, maka tidak terjadi heterokedastisitas. Model regresi yang baik adalah bebas dari masalah heterokedastisitas (Ghozali, 2005; 91). Hasil analisis uji heteroskedastisitas ditunjukkan dalam grafik berikut:

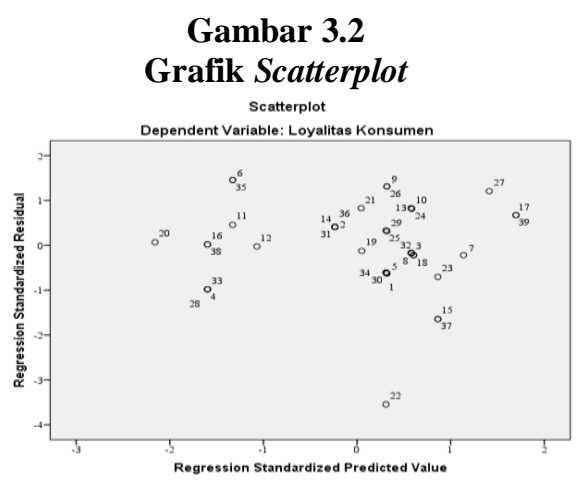

Dari grafik Scatterplot diatas menunjukkan bahwa nilai-nilai sebaran data penelitian tersebar secara acak, tidak membentuk suatu pola tertentu yang jelas, tersebar baik diatas maupun dibawah angka nol pada sumbu Y. Hal ini berarti tidak terjadi heterokedastisitas pada model regresi, sehingga model regresi layak digunakan. 


\section{HASIL DAN PEMBAHASAN \\ Hasil Uji Regresi}

Analisis regresi linear berganda digunakan untuk mengetahui seberapa besar pengaruh faktor yang digunakan dalam model penelitian yaitu faktor citra merek dan kepuasan konsumen terhadap loyalitas konsumen. Berdasarkan hasil olah data statistik yang telah dianalisis diperoleh hasil sebagai berikut:

Tabel 3. Hasil Uji Regresi Linear Berganda

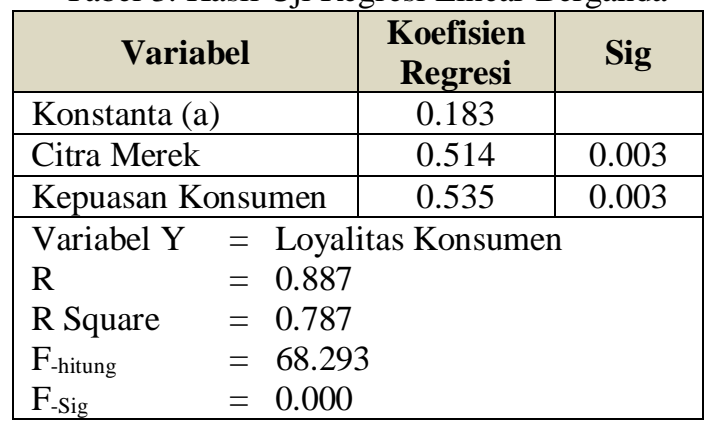

Dari nilai-nilai yang ditunjukkan pada tabel di atas, diperoleh persamaan model regresi sebagai berikut:

$$
\mathrm{Y}=0.183+0.514 \mathrm{X}_{1}+0.535 \mathrm{X}_{2}
$$

Persamaan regresi di atas memberikan gambaran mengenai besarnya pengaruh variabel bebas terhadap variabel terikat. Dimana dari koefisien regresi $\mathrm{X}_{1}$ (Citra Merek), dan $\mathrm{X}_{2}$ (Kepuasan Konsumen), yang bertanda positif $(+)$ menunjukkan bahwa terdapat pengaruh positif yang searah antara variabel bebas $\left(X_{1}\right.$, dan $\left.X_{2}\right)$ dengan variabel terikat $(\mathrm{Y})$.

Persamaan regresi sebagaimana yang telah diuraikan sebelumnya dapat pula dijelaskan sebagai berikut:

a) Nilai konstanta sebesar 0,183, memberikan arti bahwa jika variabel bebas (citra merek dan kepuasan konsumen) diasumsikan bernilai 0 , maka loyalitas konsumen akan naik sebesar 0,183 apabila variabel lain dianggap konstan.

b) Nilai koefisien regresi variabel citra merek $\left(\mathrm{X}_{1}\right)$ sebesar 0,514, memberikan makna bahwa citra merek berpengaruh positif terhadap loyalitas konsumen, hal ini berarti jika Sim Card Telkomsel meningkatkan citra mereknya dengan yang lebih baik lagi maka akan meningkatkan loyalitas konsumen. Peningkatan citra merek dapat dilakukan dengan meningkatkan kualitas dan teknologi, sehingga konsumen merasa puas dan loyalitas akan tercipta. c) Nilai koefisien regresi variabel kepuasan konsumen $\left(\mathrm{X}_{2}\right)$ sebesar 0,535 , memberikan makna bahwa kepuasan konsumen berpengaruh positif terhadap loyalitas konsumen, hal ini berarti jika perusahaan meningkatkan kepuasan konsumen maka akan meningkatkan loyalitas konsumen. Peningkatan kepuasan konsumen dapat dilakukan dengan memberikan pelayanan yang terbaik bagi konsumen sehingga konsumen merasa puas dan nyaman menggunakan Sim Card Telkomsel.

Temuan ini di dukung pula oleh hasil koefisien korelasi dan koefisien determinasi. Koefisien determinasi pada intinya mengukur seberapa jauh kemampuan sebuah model dalam menerangkan variasi variabel terikat. Hasil analisis sebagaimana ditunjukkan pada Tabel.3 di atas menunjukkan bahwa nilai koefisien determinasi yang dilihat dalam nilai $R$ Square adalah sebesar 0,787. Nilai ini memberi arti bahwa loyalitas konsumen Sim Card Telkomsel dipengaruhi oleh citra merek dan kepuasan konsumen sebesar 78,7 persen, sementara selebihnya yaitu 21,3 persen dipengaruhi oleh faktor lain di luar variabel yang diteliti.

Selanjutnya nilai koefisien korelasi (R) menunjukkan keeratan atau hubungan antara faktor citra merek dan kepuasan konsumen dengan loyalitas konsumen Sim Card Telkomsel. Hasil perhitungan sebagaimana ditunjukkan pada Tabel.3 membuktikan bahwa nilai koefisien korelasi (R) adalah sebesar 0,887. Nilai ini memberikan arti bahwa antara citra merek dan kepuasan konsumen dengan loyalitas konsumen Sim Card Telkomsel, terdapat hubungan sebesar 0,887 atau 88,7 persen.

Kuat tidaknya hubungan tersebut, peneliti merujuk pada pernyataan Sugiyono (2011; 162), sebagai berikut:

a) Jika nilai $\mathrm{R}=0,00-0,199$ hubungan sangat rendah

b) Jika nilai $\mathrm{R}=0,20-0,399$ hubungan rendah

c) Jika nilai $\mathrm{R}=0,40-0,599$ hubungan sedang

d) Jika nilai $R=0,60-0,799$ hubungan kuat

e) Jika nilai $\mathrm{R}=0,80-1,000$ hubungan sangat kuat

Dengan demikian maka terdapat hubungan yang sangat kuat $(88,7 \%)$ antara variabel citra merek dan kepuasan konsumen dengan variabel loyalitas konsumen Sim Card Telkomsel. 


\section{Hasil Uji Hipotesis Pertama}

Hipotesis pertama dalam penelitian ini menyatakan bahwa faktor citra merek dan kepuasan konsumen secara serempak berpengaruh positif dan signifikan terhadap loyalitas konsumen Sim Card Telkomsel. Pengujian hipotesis pertama dianalisis dengan menggunakan analisis regresi linier berganda. Uji kelayakan model akan dianalisa dengan membandingkan nilai probabilitas pada output Uji-F dengan level of significant $5 \%$. Kriteria pengambilan keputusan adalah Jika nilai signifikansi $<$ nilai $\alpha=0,05$ maka variabel bebas berpengaruh signifikan terhadap variabel terikat. Jika nilai signifikansi $>$ nilai $\alpha=$ 0,05 maka variabel bebas tidak berpengaruh signifikan terhadap variabel terikat. Hasil uji regresi linear berganda sebagaimana terlihat pada Tabel.3 di atas, menunjukkan bahwa nilai signifikansi $\left(\mathrm{F}_{-}\right.$Sig $)$sebesar 0,000 lebih kecil dari nilai $\alpha=0,05$. Ini berarti bahwa variabel citra merek dan kepuasan konsumen secara serempak berpengaruh signifikan terhadap loyalitas konsumen Sim Card Telkomsel. Dengan demikian hipotesis pertama yang diajukan dalam penelitian ini dapat diterima dan terbukti kebenarannya.

\section{Hasil Uji Hipotesis Kedua}

Hipotesis kedua dalam penelitian ini menyatakan bahwa citra merek berpengaruh positif dan signifikan terhadap loyalitas konsumen Sim Card Telkomsel. Pengujian hipotesis kedua ini dianalisis dengan menggunakan analisis regresi linier berganda. Uji kelayakan model akan dianalisa dengan membandingkan nilai probabilitas pada output Uji-t dengan level of significant 5\%. Penerimaan atau penolakan hipotesis dilakukan dengan kriteria jika nilai signifikansi $>$ nilai $\alpha=0,05$ maka hipotesis ditolak. Jika nilai signifikansi $<$ nilai $\alpha=0,05$ maka hipotesis di terima. Hasil uji regresi linear berganda sebagaimana Tabel.3 di atas, menunjukkan bahwa nilai signifikansi $(\mathrm{t}-\mathrm{Sig})$ variabel citra merek sebesar 0,003 lebih kecil dari nilai $\alpha=0,05$. Ini membuktikan bahwa secara parsial variabel citra merek berpengaruh signifikan terhadap loyalitas konsumen Sim Card Telkomsel. Dengan demikian hipotesis kedua dalam penelitian ini diterima dan terbukti kebenarannya.

\section{Hasil Uji Hipotesis Ketiga}

Hipotesis ketiga dalam penelitian ini
menyatakan bahwa kepuasan konsumen berpengaruh positif dan signifikan terhadap loyalitas konsumen Sim Card Telkomsel. Pengujian hipotesis ketiga ini dianalisis dengan menggunakan analisis regresi linier berganda. Uji kelayakan model akan dianalisa dengan membandingkan nilai probabilitas pada output Uji-t dengan level of significant 5\%. Penerimaan atau penolakan hipotesis dilakukan dengan kriteria jika nilai signifikansi $>$ nilai $\alpha=0,05$ maka hipotesis di tolak. Jika nilai signifikansi $<$ nilai $\alpha$ $=0,05$ maka hipotesis di terima. Hasil uji regresi linear berganda sebagaimana Tabel.3 di atas, menunjukkan bahwa nilai signifikansi ( $\left.\mathrm{t}_{\text {sig }}\right)$ variabel kepuasan konsumen sebesar 0,003 lebih kecil dari nilai $\alpha=0,05$. Ini membuktikan bahwa secara parsial variabel kepuasan konsumen berpengaruh signifikan terhadap loyalitas konsumen Sim Card Telkomsel. Dengan demikian hipotesis ketiga dalam penelitian ini diterima dan terbukti kebenarannya.

\section{Pembahasan}

Penelitian ini bertujuan untuk menguji, menganalisis serta mengetahui pengaruh citra merek dan kepuasan konsumen terhadap loyalitas konsumen Sim Card Telkomsel. Hasil penelitian ini menguji pengaruh citra merek dan kepuasan konsumen terhadap loyalitas konsumen. Didapatkan hasil bahwa pengaruh citra merek dan kepuasan konsumen memiliki pengaruh yang signifikan terhadap loyalitas konsumen.

Pengaruh citra merek yang diuji terhadap loyalitas konsumen menunjukkan bahwa citra merek berpengaruh signifikan terhadap loyalitas konsumen dan nilai koefisien regresi yang terjadi dalam penelitian ini adalah positif. Citra merek merupakan kumpulan persepsi yang dimiliki konsumen untuk mengetahui seberapa besar merek tersebut tersimpan didalam memori mereka. Citra yang diyakini oleh konsumen terhadap suatu merek sangat bervariasi tergantung pada persepsi masing-masing individu. Apabila suatu produk memiliki citra merek positif dan diyakini oleh konsumen dapat memenuhi kebutuhan dan keinginannya, maka dengan sendirinya akan menumbuhkan loyalitas konsumen terhadap suatu merek. Sebaliknya jika citra merek suatu produk negatif dimata konsumen, maka loyalitas konsumen terhadap produk akan berkurang, bahkan bisa juga konsumen tidak loyal terhadap produk tersebut. Hasil penelitian ini sejalan dengan penilitian yang dilakukan Gani Prabowo (2012), Putri Andeni 
(2015), dan Wulandari (2017) yang dimana mengemukakan bahwa citra merek berpengaruh positif dan signifikan terhadap loyalitas konsumen.

Pengaruh kepuasan konsumen yang diuji terhadap loyalitas konsumen menunjukkan bahwa kepuasan konsumen berpengaruh signifikan terhadap loyalitas konsumen dan nilai koefisien regresi yang terjadi dalam penelitian ini adalah positif. Kepuasan konsumen respon atau tanggapan konsumen mengenai pemenuhan kebutuhan yang diterima konsumen. Pada umumnya konsumen yang telah menggunakan produk atau jasa suatu perusahaan akan merasakan puas atau tidaknya terhadap produk maupun jasa. Berdasarkan pengalaman yang diperolehnya konsumen memiliki kecenderungan untuk membangun nilai-nilai ekspektasi tertentu. Nilai ekspektasi tersebut akan memberikan dampak bagi konsumen untuk melakukan perbandingan terhadap kompetitor dari produk yang pernah dirasakannya. Secara langsung penilaian tersebut akan mempengaruhi pandangan dan penilaian konsumen terhadap perusahaan kompetitor. Konsumen yang loyal belum tentu berarti puas. Sebaliknya konsumen yang puas cerderung untuk menjadi konsumen yang loyal. hasil penelitian ini menunjukkan bahwa variabel kepuasan konsumen memiliki pengaruh yang signifikan terhadap loyalitas konsumen Sim Card Telkomsel di Ampana Kota. Hasil penelitian ini sejalan dengan penilitian yang dilakukan Gani Prabowo (2012), dan Wulandari (2017) yang dimana mengemukakan kepuasan konsumen berpengaruh positif dan signifikan terhadap loyalitas konsumen.

\section{KESIMPULAN DAN SARAN Kesimpulan}

Berdasarkan hasil pembahasan sebelumnya, maka dapat ditarik kesimpulan sebagai berikut:

1. Citra merek dan kepuasan konsumen secara serempak berpengaruh positif dan signifikan terhadap loyalitas konsumen Sim Card Telkomsel di Ampana Kota.

2. Citra merek berpengaruh positif dan signifikan terhadap loyalitas konsumen Sim Card Telkomsel di Ampana Kota.

3. Kepuasan konsumen berpengaruh positif dan signifikan terhadap loyalitas konsumen Sim Card Telkomsel di Ampana Kota.
Saran

Berdasarkan hasil pembahasan dalam penelitian ini, serta pengetahuan dan pengalaman yang peneliti dapatkan selama proses penelitian, maka dikemukakan saran-saran sebagai berikut:

1. Bagi Perusahaan

a. Agar melakukan peningkatan dari segi citra merek dan kepuasan konsumen dengan melakukan riset keinginan dari konsumen dan melakukan penelitian terhadap konsumen untuk mengetahui apa yang diinginkan konsumen.

b. Melakukan riset mengenai faktor apa saja yang mempengaruhi loyalitas konsumen, karena masih ada faktor-faktor lain yang belum dapat dijelaskan dalam penelitian ini.

c. Berdasarkan hasil penelitian, perusahaan harus melakukan peningkatan dari segala bidang untuk meningkatkan citra merek dan kepuasan konsumen.

2. Bagi Akademisi

a. Bagi pihak yang ingin melakukan penelitian yang sejenis, disarankan untuk meneliti variabel-variabel lain selain citra merek dan kepuasan konsumen. Karena dari penelitian ini diketahui 21,3 persen masih ada faktor-faktor lain yang mempengaruhi loyalitas konsumen.

b. Untuk memperkuat hasil penelitian serupa dianjurkan menambah sampel dan menjelaskan proses pengisian kuesioner dan mendampingi responden ketika mengisi kuesioner tersebut.

\section{DAFTAR PUSTAKA}

Dajan, Anton. 1992. Pengantar Statistik. Jilid II. Jakarta: LP3ES

Gani, Prabowo. 2012. Pengaruh Citra Merek dan Kepuasan Pelanggan Terhadap Loyalitas Pelanggan Kartu Seluler XL Prabayar di Surabaya. Skripsi. Surabaya: Fekon UPN Veteran

Ghozali, Imam. 2005. Aplikasi Analisis Multivariate dengan SPSS. Semarang: Badan Penerbit UNDIP

Griffin, Jill. 2009. Customer Loyalty: Menumbuhkan Dan Mempertahankan Pelanggan. Jakarta: Airlangga

Kotler, Philip. 2007. Manajemen Pemasaran. Jakarta: PT.Indeks 
Kotler, Philip and Gary Armstrong. 2008. Prinsipprinsip Pemasaran. Edisi 12. Jilid 1. Jakarta: Erlangga

Kotler, dan Keller. 2009. Manajemen Pemasaran, Jilid 1 dan 2, Edisi Kesebelas. Jakarta: PT. Indeks

Lovelock, Christopher H. 2007. Manajemen Pemasaran Jasa, Alih bahasa Agus Widyantoro, Cetakan Kedua. Jakarta: Indeks

Putri, Andeni. 2015. Pengaruh Citra Merek dan Kualitas Pelayanan Terhadap Loyalitas Pelanggan Telkomsel di Grapari Telkomsel Tebing Tinggi. Skripsi. Medan: FEB-Universitas Sumatera Utara

Rangkuti, Freddy. 2009. Analisis SWOT Tekhnik Membedah Kasus Bisnis. Jakarta: Gramedia Pustaka Utama

Santoso, Singgih. 2011. Statistik Non Parametrik Konsep dan Aplikasi dengan SPSS. Jakarta: Elex Media Komputindo

Schiffman, Kanuk. 2008. Perilaku Konsumen. Edisi 7. Jakarta: Indeks

Sugiyono. 2011. Metode Penelitian Kuantitatif Kualitatif dan R\&D. Bandung: Alfabeta

Swastha, Basu. 2007. Manajemen Pemasaran Modern. Yogyakarta: Liberty Offset

Tjiptono, Fandy. 2006. Manajemen Jasa. Edisi Pertama. Yogyakarta: Andi

Tjiptono, Fandy. 2011. Strategi Pemasaran. Edisi 3. Yogyakarta: Andi

Wulandari. 2017. Pengaruh Iklan, Citra Merek, Harga, dan Kepuasan Konsumen Terhadap Loyalitas Konsumen Dalam Menggunakan Paket Data Internet Telkomsel Flash (Studi pada Konsumen Pengguna Telkomsel Flash di Bandar Lampung). Skripsi. Tidak Dipublikasikan 